\title{
Tıbbi Bitki Lysimachia nummularia L.'nın Boğum Eksplantlarından In Vitro Mikroçoğaltımı
}

\section{Muhammet DOĞAN (D)}

Karamanoğlu Mehmetbey Üniversitesi, Kamil Özdağ Fen Fakültesi, Biyoloji Bölümü, Yunus Emre Kampusu, 70100, Karaman, Türkiye.

$\bowtie:$ mtdogan1@gmail.com

\section{ÖZET}

Lysimachia nummularia L. Avrupa ve Asya'da çeşitli hastalıkların tedavisinde geleneksel olarak kullanılan önemli bir bitkidir. İçerdiği değerli biyoaktif bileşiklerden dolayı farmasötik alanda oldukça önemli bir yere sahiptir. Bu çalışmada, L. nummularia'nın doku kültürü teknikleri ile üretimi araştırılmıştır. L. nummularia'nın boğum eksplantları farklı konsantrasyonlarda 6-Benzilaminopurin (BAP)'i tek olarak veya İndol-3-Bütirik Asit (IBA) ile kombinasyonunu içeren Murashige ve Skoog (MS) besin ortamında kültüre alınmıştır. Genel olarak her iki hormon denemelerinde yüksek sürgün rejenerasyon yüzdeleri elde edilmiştir. Maksimum eksplant başına sürgün sayısı (12.27 adet) $1.6 \mathrm{mg} \mathrm{L}^{-1}$ BAP içeren MS besin ortamında, ardından $0.8 \mathrm{mg} \mathrm{L}^{-1} \mathrm{BAP}+0.1 \mathrm{mg} \mathrm{L}^{-1}$ IBA içeren MS besin ortamında (11 adet) elde edilmiştir. En düşük sürgün sayısı her iki hormon uygulamasında da $0.05 \mathrm{mg} \mathrm{L}^{-1}$ BAP içeren MS besi ortamında tespit edilmiştir. Kültür ortamında BAP konsantrasyonunun artması ile sürgün sayısı artış göstermiştir. En uzun sürgünler $0.1 \mathrm{mg} \mathrm{L^{-1 }}$ BAP eklenmiş $\mathrm{MS}$ ortamında $(4.6 \mathrm{~cm})$ ve $0.1 \mathrm{mg} \mathrm{L}^{-1} \mathrm{BAP}+0.1 \mathrm{mg} \mathrm{L}^{-1}$ IBA eklenmiş MS ortamında $(4.52 \mathrm{~cm})$ kaydedilmiştir. En kısa sürgün uzunlukları $1.6 \mathrm{mg} \mathrm{L}^{-1} \mathrm{BAP}$ eklenmiş MS ortamında tespit edilmiştir. Kültür ortamlarındaki rejenere sürgünler yoğun kök oluşturdukları için ayrıca köklendirme çalışması yapılmamıştır. Köklü bitkiler başarılı şekilde akvaryum ortamına alıştırılmıştır. Sonuç olarak L. nummularia'nın doku kültürü teknikleri ile üretimi için en iyi hormon $1.6 \mathrm{mg} \mathrm{L}^{-1}$ BAP olarak tespit edilmiştir. Bu çalışma, L. nummularia'nın doku kültürü ile çoklu üretimine imkan sağlayarak, bu bitkiden değerli bitkisel metabolitlerin yüksek miktarlarda elde edilmesine yardımcı olabilir. Böylece gıda ve farmasötik sektörlere katkı sunulabilir.
DOI:10.18016/ksutarimdoga.vi.452927

\section{Makale Tarihçesi}

Geliş Tarihi : 28.01.2018

Kabul Tarihi : 05.06.2018

\author{
Anahtar Kelimeler \\ BAP, \\ in vitro çoğaltım, \\ L. nummularia, \\ sürgün rejenerasyonu
}

Araştırma Makalesi

In Vitro Micropropagation from Nodal Explants of the Medicinal Plant Lysimachia nummularia L.

\section{Article History}

Received : 28.01.2018

Accepted : 05.06.2018

\author{
Keywords \\ BAP, \\ in vitro propagation, \\ L. nummularia, \\ shoot regeneration
}

\section{Research Article}


the regenerated shoots in the culture medium sustaine intensive roots, rooting experiments have not been carried out. The rooted plants were successfully acclimatized to the aquarium environment. As a result, the best hormone for the propagation of $L$. nummularia by tissue culture techniques was $1.6 \mathrm{mg} \mathrm{L} \mathrm{m}^{-1} \mathrm{BAP}$. This work may help to obtain high amounts of this valuable herbal metabolite by allowing multiple production of L. nummularia with tissue culture. Thus, it can be contributed to the food and pharmaceutical sectors.

To cite: Doğan M 2018. Tıbbi Bitki Lysimachia nummularia L.'nın Boğum Eksplantlarından In Vitro Mikroçoğaltımı. KSÜ Tar Doğa Derg 21(6) : 875-881, DOI : 10.18016/ksutarimdoga.vi.452927

\section{GİRIŞ}

Bitki doku ve organ kültürü, morfogenez gibi bazı birincil biyolojik mekanizmaların incelenmesi ve anlaşılması için 20. yüzyılın başından itibaren yoğun şekilde kullanılmıştır. Bununla birlikte, bitkilerden türetilen yeni ürünlere yönelik pazar talebinin artmasıyla in vitro çoğaltım, bitki materyalinin seri üretimi için güvenilir bir teknik haline gelmiştir. Ayrıca, fenolik bileşikler gibi bazı biyoaktif bileşiklerin bitkilerden eldesi için de bu teknik oldukça büyük avantajlar sağlamaktadır (Dias ve ark., 2016).

Bitki doku kültürü, ana bitkiden izole edilen bitki parçalarının steril koşullar altında yapay bir besin ortamında büyütülmesi olarak tanımlanmıştır. Bu teknik esas olarak bitki hücresinin totipotensi özelliğine bağlıdır. Totipotensi, tek bir hücrenin hücre bölünmeleriyle tüm genomu oluşturma yeteneğidir (Neumann ve ark., 2009; Hussain ve ark., 2012). Doku kültürü tekniği kullanılarak bitkilerin üretilmesi çalışmaları son yıllarda da hızla devam etmektedir. Bu bitkilere örnek olarak Ceratophyllum demersum L. (Karatas ve ark., 2015), Hypoxis hemerocallidea (Kumar ve ark. 2017), Kelussia odorotissima Mozaff. (Ebrahimi ve ark. 2018), Urginea altissima (L.f.) Baker (Baskaran ve ark. 2018), Alectra chitrakutensis (Sharma ve ark. 2018) verilebilir.

Lysimachia nummularia L. (Primulaceae) Avrasya'ya özgü ve su gövdeleri yakınında, bataklıklarda ve diğer nemli habitatlarda yetişen, sürünen, uzun ömürlü bir bitkidir (Kodela Jobson, 2016). L. nummularia, özellikle Bolu, Bartın, Zonguldak (Başaranve Adıgüzel, 2001.) ve Samsun (Yılmaz ve Kormaz, 2017) gibi Karadeniz Bölgesi başta olmak üzere ülkemizin sulak ve ormanlık alanlarda rastlanılmaktadır. $L$. nummularia tıbbi değeri ile bilinmektedir (Hanganu ve ark., 2016) ve çok sayıda farmakolojik araştırmanın konusu olmuştur (Podolak ve ark., 2013a). Lysimachia cinsine ait bitkilerin antik çağdan beri diyare, ateş, artrit, tüberküloz, deri hastalıkları gibi endikasyonlar için kullanılmıştır. Analjezik, antiliskemik, antihelmintik özelliklerine dair raporlar bulunmaktadır (Li ve ark., 2009; Challam ve ark., 2010; Yang ve ark., 2011; Hanganu ve ark., 2016). L. nummularia'nın
Streptococcus pyogenes, Staphylococcus aureus, Salmonella sp. ve Shigella $s p$. gibi birçok bakterilere karşı antimikrobiyal aktivite gösterdiği de bildirilmiştir (Podolak ve ark., 2013a). Ayrıca, L. nummularia'dan trifolin, izokerkitrin, mrikitrin, mearnsitrin, siringülin 3-galaktozid, kaempferol 3-Oramnosil $(1 \rightarrow 2)$ galaktozid, quercetin 3-0neohesperidioside, rutin, kaempferol 3- $O^{-(2.6-}$ diramnosilgalaktosid) ve quercetin $3-O^{-}\left(2.6^{-}\right.$ dirhamnosylgalactoside) gibi değerli bileşikler ile polifenoller, terpenler, flavonidler izole edilmiştir (Yasukawa ve ak., 1990; Podolak ve ark., 2013b; Toth ve ark., 2014; Toth ve ark., 2017). Bu çalışmada, tıbbi öneme sahip L. nummularia'nın boğum eksplantlarından doku kültürü teknikleri ile hızlı ve çoklu üretimi hedeflenmiştir. Bu bitkinin doğal yollar ile (tohum veya vejetatif olarak) çoğaltımı uzun zaman almaktadır. Bitkilerin üretim yerinin kısıtlı olması ve istenilen miktarda bitki üretilmesinin zor olması nedeniyle bu çalışmada doku kültürü tekniği kullanılmıştır. Bu yöntem ile mevsime ve dış koşullara bağlı kalmadan yılın her döneminde istenildiği kadar bitki üretimi yapılabilir. Ayrıca bu yöntem, kısa sürelerde ve küçük alanlarda kitlesel bitki üretimine imkan sağlamaktadır.

\section{MATERYAL ve METOT}

Bitki materyali olarak kullanılan Lysimachia nummularia L., Konya'da bulunan akvaryumculardan 50 adet olarak temin edilmiştir. Yüzey sterilizasyonu işlemi uygulanmadan önce $30 \mathrm{dk}$ akan çeşme suyunun altında bekletilmiştir. Bitkilerin yüzey sterilizasyonu ticari çamaşır suyu (\%5.7 aktif klor-NaOCI-ACE) ile 10 $\mathrm{dk}$ muamele ile edilmiştir. $5 \mathrm{dk}$ süreyle $3 \mathrm{kez}$ durulama işlemi uygulandıktan sonra boğum eksplantları izole edilerek, hormonsuz Murashige ve Skoog (1962) (MS) ortamına aktarılmıştır. Denemeler petri kaplarında 6 tekerrürlü olarak yürütülmüştür. Herbir petri kabına 6 adet boğum eksplantı yerleştirilmiştir. Kültür ortamlarının hazırlanmasında MS tuzları (Çizelge 1), \%3 sakkaroz (Duchefa) ve \%0.65'lik agar (Duchefa) kullanılmıştır. 
Çizelge 1. Murashige ve Skoog (1962) temel besin ortamı bileşenleri

\begin{tabular}{|c|c|c|}
\hline \multicolumn{2}{|l|}{ Bileşenler } & Konsantrasyon $\left(\mathrm{mg} \mathrm{L}^{-1}\right)$ \\
\hline \multirow{5}{*}{ Makro Elementler } & $\mathrm{NH}_{4} \mathrm{NO}_{3}$ & 1650.000 \\
\hline & $\mathrm{KNO}_{3}$ & 1900.000 \\
\hline & $\mathrm{CaCI}_{2} .2 \mathrm{H}_{2} \mathrm{O}$ & 440.000 \\
\hline & $\mathrm{MgSO}_{4 .} 7 \mathrm{H}_{2} \mathrm{O}$ & 370.000 \\
\hline & $\mathrm{KH}_{2} \mathrm{PO}_{4}$ & 170.000 \\
\hline \multirow{9}{*}{ Mikro Elementler } & KI & 0.830 \\
\hline & $\mathrm{H}_{3} \mathrm{BO}_{3}$ & 6.200 \\
\hline & $\mathrm{MnSO}_{4} 4 \mathrm{H}_{2} \mathrm{O}$ & 22.300 \\
\hline & $\mathrm{ZnSO}_{4} .7 \mathrm{H}_{2} \mathrm{O}$ & 8.600 \\
\hline & $\mathrm{Na}_{2} \mathrm{MoO}_{4} .2 \mathrm{H}_{2} \mathrm{O}$ & 0.250 \\
\hline & $\mathrm{FeSO}_{4} .7 \mathrm{H}_{2} \mathrm{O}$ & 27.850 \\
\hline & $\mathrm{CoCl}_{2} .6 \mathrm{H}_{2} \mathrm{O}$ & 0.025 \\
\hline & $\mathrm{CuSO}_{4} .5 \mathrm{H}_{2} \mathrm{O}$ & 0.025 \\
\hline & $\mathrm{Na}_{2}$ EDTA. $2 \mathrm{H}_{2} \mathrm{O}$ & 37.250 \\
\hline \multirow{5}{*}{ Vitaminler } & Myo-Inositol & 100.000 \\
\hline & Nicotinic Acid & 0.500 \\
\hline & Pyrotinic Acid & 0.500 \\
\hline & Thiamine-HCI & 0.10 \\
\hline & Glycine & 2.000 \\
\hline
\end{tabular}

Denemelerde kültür ortaminda $0.05-1.6 \mathrm{mg} \mathrm{L}^{-1} 6^{-}$ benzilaminopurin (BAP) tek olarak ve $0.05-1.6 \mathrm{mg} \mathrm{L}^{-1}$ $\mathrm{BAP}+0.1 \mathrm{mg} \mathrm{L} \mathrm{L}^{-1}$ Indol-3 bütirik asit (IBA) kombinasyonları kullanılmıştır (Çizelge 2). $1 \mathrm{~N} \mathrm{NaOH}$ ve $1 \mathrm{~N} \mathrm{HCl}$ ile kültür ortamının $\mathrm{pH}$ 'sı $5.7 \pm 0.1$ 'e yapılmış ve otoklavda steril edilmiştir ( 1.2 basınç $-120^{\circ} \mathrm{C}$ 'de $20 \mathrm{dk}$ ). Denemelerde eksplantlar, beyaz işık yayan diyotlar (LED) $24 \pm 1^{\circ} \mathrm{C}^{\prime}$ de ve 16 saat ışık fotoperiyodunda kültüre alınmıştır. Rejenerasyon çalışmalarında eksplantlar bir kez kültür ortamında alınmış olup, sekiz hafta sonunda deneme sonlandırılmıştır. Rejenere sürgünlerin üzerindeki besin ortamı akan çeşme suyu altında tutularak arındırıldıktan sonra bitkiler, dış koşullara alıştırılmak için akvaryum ortamına aktarılmıştır. Akvaryum tabanına 4-5 cm yüksekliğinde dere kumu $(10 \mathrm{~kg})$ yerleştirilmiş olup, $24^{\circ} \mathrm{C}$ sicaklık ayarlı termostat ve 16 saat fotoperityodunda aydınlatma kullanılmıştır. Ayrıca akvaryum suyuna sıvı gübre ilave edilmiştir (Sera - Florena).

Çizelge 2. In vitro çoğaltımda kullanılan bitki büyüme düzenleyicileri

\begin{tabular}{|c|c|}
\hline BAP $\left(\mathrm{mg} \mathrm{L}^{-1}\right)$ & IBA $\left(\mathrm{mg} \mathrm{L}^{-1}\right)$ \\
\hline 0.05 & 0.1 \\
\hline 0.1 & 0.1 \\
\hline 0.2 & 0.1 \\
\hline 0.4 & 0.1 \\
\hline 0.8 & 0.1 \\
\hline 1.6 & 0.1 \\
\hline
\end{tabular}

Tüm denemeler tesadüf parselleri deneme desenine göre kurulmuştur. Doku kültürü çalışmaları 6 tekerrürlü olarak yürütülmüştür. Elde edilen veriler SPSS 21 for Windows (Statistical Package for the Social Sciences version 21.0. IBM Corporation, Armonk, NY, USA) programı ile analiz edilmiş ve Post Hoc testleri için de Duncan testleri uygulanmıştır.

\section{BULGULAR ve TARTIŞMA}

L. nummularia'nın boğum eksplantları sürgün rejenerasyonu için $0.05-1.6 \mathrm{mg} \mathrm{L}^{-1} \mathrm{BAP}$ ve $0.1 \mathrm{mg} \mathrm{L}^{-1}$ IBA kombinasyonu içeren MS besin ortamında kültüre alınmıştır. Kültür ortamlarında herhangi bir kontaminasyon gözlemlenmemiştir. Her iki kültür ortamında da ikinci haftanın sonunda doğru sürgün oluşumları ve kök rejenerasyonları gözlenmeye başlanmıştır. Dört hafta sonunda ise çoklu sürgün ve kök oluşumları belirgin şekilde gözlenmeye başlamıştır. Sekizinci hafta sonunda BAP (Şekil $1 \mathrm{a}, \mathrm{b}$ ) ve BAP + IBA (Şekil 2 a,b) hormonunun etkisiyle büyüyen ve uzayan sürgünler kayıt altına alınmış ve elde edilen veriler ile varyans analizi uygulamıştır (Çizelge 3). Benzer şekilde BAP içeren kültür ortamında Musa acuminata (banana) cv. Berangan (Jafari ve ark., 2011), Tylophora indica (Soni ve Bhushan, 2017) ve Sesamum indicum L. (Zimik ve Arumugam, 2017) bitkilerinin de üretimi bildirilmiştir. Varyans analizlerinden görüldüğü gibi sürgün rejenerasyon oranı, eksplant başına sürgün sayısı ve sürgün uzunluğu bakımından ortamlar arasında istatistiki olarak $p<0.01$ düzeyinde önemli bir farklılık çıkmıştır. Bu farklılığın önem derecesini belirlemek amacıyla Duncan testi sonuçları Çizelge 4 'te verilmiştir. 


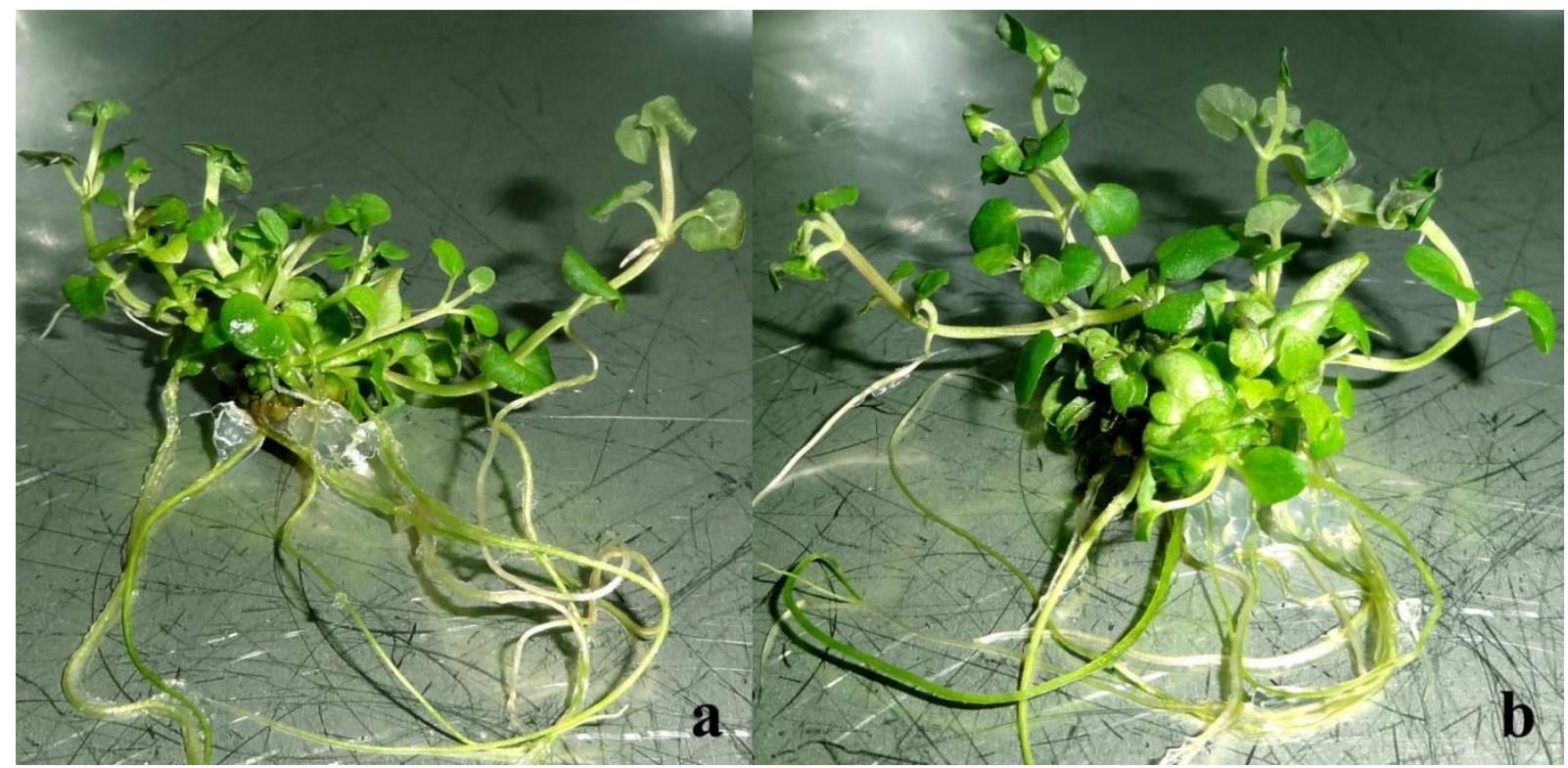

Şekil 1. Farklı BAP dozlarının L. nummulariảnin boğum eksplantlarından sürgün rejenerasyonu ve kök oluşumları; (a) $0.8 \mathrm{mg} \mathrm{L}^{-1} \mathrm{BAP}$ (b) $1.6 \mathrm{mg} \mathrm{L}^{-1} \mathrm{BAP}$ içeren MS ortamında çoklu sürgün oluşumları ve uzun kökler

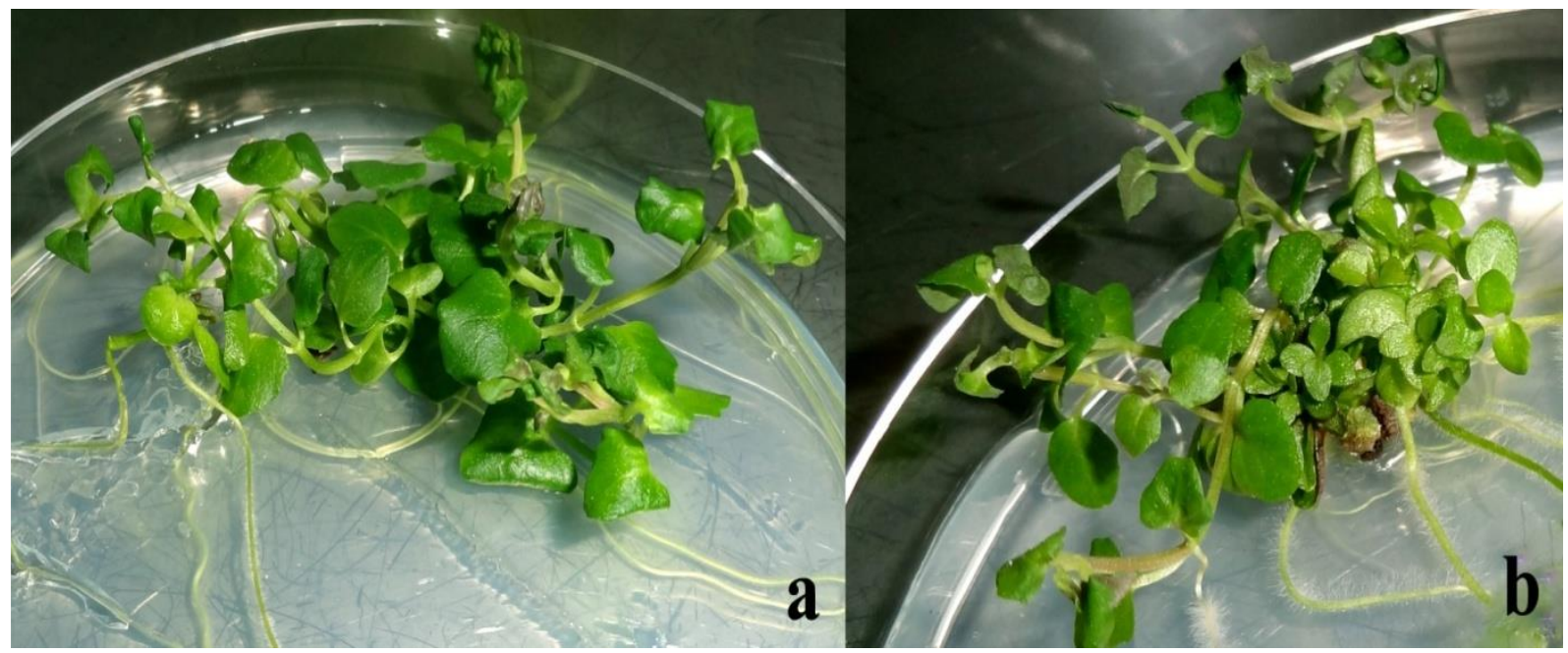

Şekil 2. $0.1 \mathrm{mg} \mathrm{L}^{-1} \mathrm{IBA}$ ve farklı BAP dozlarının L. nummularia’nin boğum eksplantlarından sürgün rejenerasyonu; (a) $0.4 \mathrm{mg} \mathrm{L}^{-1} \mathrm{BAP}+0.1 \mathrm{mg} / \mathrm{L}$ IBA (b) $0.8 \mathrm{mg} \mathrm{L}^{-1} \mathrm{BAP}+0.1 \mathrm{mg} \mathrm{L}^{-1} \mathrm{IBA}$ içeren MS ortamında çoklu sürgün oluşumları

Çizelge 3. $0.1 \mathrm{mg} \mathrm{L} \mathrm{L}^{-1}$ IBA ve farklı BAP dozlarının L. nummulariảnin boğum eksplantından sürgün rejenerasyonuna ait varyans analizi

\begin{tabular}{|l|l|c|c|c|c|c|c|}
\hline \multirow{2}{*}{ VK } & \multirow{2}{*}{ VD } & \multicolumn{2}{|c|}{$\begin{array}{c}\text { Sürgün Rejenerasyon Oranı } \\
\text { (\%) }\end{array}$} & \multicolumn{2}{c|}{$\begin{array}{c}\text { Eksplant Bassina Sürgün } \\
\text { Sayıs (adet) }\end{array}$} & \multicolumn{2}{c|}{$\begin{array}{c}\text { Sürgün Uzunluğu } \\
\text { (cm) }\end{array}$} \\
\cline { 3 - 8 } & & KO & F & KO & F & KO & F \\
\hline Ortam & 11 & 553,33 & $3,58^{* *}$ & 28,87 & $75,61^{* *}$ & 2,29 & $12,73^{* *}$ \\
\hline Hata & 24 & 152,38 & - & 0,38 & - & 0,18 & - \\
\hline Genel toplam & 35 & - & - & - & - & - & - \\
\hline
\end{tabular}

$* * p<0.01$ düzeyinde önemli; VK:Varyans kaynağg; SD: Serbestlik derecesi; KO:Kareler ortalaması 
Çizelge 4. $0.1 \mathrm{mg} \mathrm{L} \mathrm{L}^{-1}$ IBA ve farklı BAP dozlarının L. nummularia'nin boğum eksplantından sürgün rejenerasyonuna etkisi

\begin{tabular}{|c|c|c|c|c|}
\hline \multicolumn{2}{|c|}{$\begin{array}{l}\text { Büyüme Düzenleyici } \\
\left(\mathrm{mg} \mathrm{L}^{-1}\right)\end{array}$} & \multirow{2}{*}{$\begin{array}{c}\text { Sürgün Rejenerasyon } \\
\text { Oranı (\%) }\end{array}$} & \multirow{2}{*}{$\begin{array}{c}\text { Eksplant Başına } \\
\text { Sürgün Sayısı (adet) }\end{array}$} & \multirow[t]{2}{*}{ Sürgün Uzunluğu $(\mathrm{cm})$} \\
\hline BAP & IBA & & & \\
\hline 0.05 & - & $100.00^{a}$ & $3.05^{\mathrm{e}}$ & $3.48^{\text {bcde }}$ \\
\hline 0.1 & - & $94.44^{\mathrm{ab}}$ & $3.66^{\text {de }}$ & $4.60^{\mathrm{a}}$ \\
\hline 0.2 & - & $83.33^{\mathrm{abc}}$ & $3.50^{\mathrm{e}}$ & $4.39^{\mathrm{abc}}$ \\
\hline 0.4 & - & $66.66^{\mathrm{bc}}$ & $4.44^{\text {cde }}$ & $2.97 \mathrm{def}$ \\
\hline 0.8 & - & $83.33^{\mathrm{abc}}$ & $5.33^{c}$ & $2.37^{\mathrm{fg}}$ \\
\hline 1.6 & - & $72.22^{\mathrm{abc}}$ & $12.27^{\mathrm{a}}$ & $1.84^{\mathrm{g}}$ \\
\hline 0.05 & 0.1 & $100.00^{\mathrm{a}}$ & $3.00^{\mathrm{e}}$ & $3.73^{\mathrm{abcd}}$ \\
\hline 0.1 & 0.1 & $100.00^{\mathrm{a}}$ & $3.39 \mathrm{e}$ & $4.52^{\mathrm{ab}}$ \\
\hline 0.2 & 0.1 & $61.11^{\mathrm{c}}$ & $3.91^{\text {cde }}$ & $3.58^{\mathrm{abcd}}$ \\
\hline 0.4 & 0.1 & $83.33^{\mathrm{abc}}$ & $5.06^{\mathrm{cd}}$ & $3.35^{\text {cdef }}$ \\
\hline 0.8 & 0.1 & $75.00^{\mathrm{abc}}$ & $11.00^{a}$ & 3.07 def \\
\hline 1.6 & 0.1 & $94.44^{\mathrm{ab}}$ & $6.85^{\mathrm{b}}$ & $2.50^{\mathrm{efg}}$ \\
\hline
\end{tabular}

Aynı sütunda farklı harflerle gösterilen ortalamalar arasında fark $p<0.01$ düzeyinde önemlidir.

BAP'ı tek içeren kültür ortamındaki sürgün rejenerasyon oranları \%66.66-100 arasinda tespit edilirken, BAP + IBA içeren kültür ortamında \%61.11100 arasında tespit edilmiştir (Çizelge 4). \%100 sürgün rejenerasyon oranları $0.05 \mathrm{mg} \mathrm{L}^{-1} \mathrm{BAP}$ eklenmiş MS ortaminda ve 0.05 ve $0.1 \mathrm{mg} \mathrm{L}^{-1} \mathrm{BAP}+0.1 \mathrm{mg} \mathrm{L}^{-1} \mathrm{IBA}$ eklenmiş MS besin ortaminda elde edilmiştir. En düşük sürgün rejenerasyonları ise \%66.66 ile MS + 0.4 $\mathrm{mg} \mathrm{L}^{-1}$ BAP ortaminda ve $\% 61.11$ ile $\mathrm{MS}+0.2 \mathrm{mg} \mathrm{L}^{-1}$

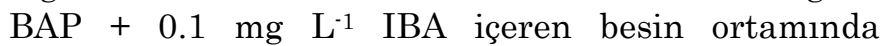
belirlenmiştir. Genel olarak en yüksek sürgün rejenerasyonları düşük hormon oranlarında kaydedilmiştir. Benzer şekilde Trivedi ve Joshi (2014) 2-25 $\mu \mathrm{M} \quad \mathrm{BAP}$ eklemiş kültür ortamında Stereospermum suaveolens DC.'in boğum eksplantlarından \%100 sürgün rejenerasyonlarını 4 ve $8 \mu \mathrm{M}$ BAP ortaminda elde etmiştir. Zheng ve ark. (2009) 1.0-5.0 mg L-1 BAP + $0.1 \mathrm{mg} \mathrm{L}^{-1} \mathrm{NAA}$ içeren MS ortamında $L$. nummularia'nın sürgün ucu eksplantları ile yürüttükleri çalışmada en yüksek sürgün rejenerasyonunu \%97.10 olarak $3.0 \mathrm{mg} \mathrm{L}^{-1} \mathrm{BAP}+0.1$ mg L ${ }^{-1}$ NAA içeren MS ortamında elde etmiştir. Buna karşın, Zimik ve Arumugam (2017) 4.5-10.5 mg L-1 BAP içeren kültür ortamında $S$. indicum'nın kotiledon eksplantlarından en yüksek sürgün rejenerasyon oranını $\% 20.4 \pm 1.6$ ile $\mathrm{MS}+4.5 \mathrm{mg} \mathrm{L}{ }^{-1} \mathrm{BAP}$ içeren kültür ortamında elde etmişlerdir.

Kültür ortamlarında BAP'ın tek kullanılması sonucu elde edilen eksplant başına sürgün sayıları 3.05-12.27, BAP + IBA kombinasyonu ile birlikte ise 3-11 arasinda değişmiştir (Çizelge 4). Maksimum sürgün sayıları 12.27 adet ile $\mathrm{MS}+1.6 \mathrm{mg} \mathrm{L}^{-1} \mathrm{BAP}$ eklenmiş kültür ortaminda ve 11.0 adet ile $\mathrm{MS}+0.8 \mathrm{mg} \mathrm{L}^{-1} \mathrm{BAP}+0.1$ $\mathrm{mg} \mathrm{L}^{-1} \mathrm{IBA}$ içeren ortamda tespit edilmiştir. En düşük sürgün sayısı her iki hormon oranın da BAP'ın en düşük oranda kullanıldığ $1 \quad\left(0.05 \mathrm{mg} \quad \mathrm{L}^{-1}\right)$ kültür ortamlarında belirlenmiştir. Genel olarak kültür ortamındaki BAP dozları arttıkça eksplant başına sürgün sayısı da artış göstermiştir. Ayrıca, hormon miktarlarına bağlı olarak bitkilerde vitrifikasyon gözlenmemiştir. Benzer şekilde, Zheng ve ark. (2009) Lysimachia'nın üç önemli türü olan L. nummularia, Lysimachia christinae, Lysimachia rubinervis'nı in vitro üretimi için sürgün ucu eksplantlarını $1-5 \mathrm{mg} \mathrm{L}^{-1}$ $\mathrm{BAP}+0.1 \mathrm{mg} \mathrm{L}^{-1} \mathrm{NAA}$ içeren MS ortamında kültüre almıştır. BAP hormonun artışıla beraber, sürgün sayısın da artığını ve en yüksek sürgün sayının BAP'ı $5 \mathrm{mg} \mathrm{L} \mathrm{L}^{-1}$ içeren kültür ortamında elde ettiğini raporlamıştır. Turker ve Guner (2013), Lysimachia vulgaris ile yürüttükleri çalışmada en iyi sürgün rejenerasyonlarını yaprak eksplantı için $0.5 \mathrm{mg} \mathrm{L}^{-1}$ BAP ve $0.1,0.5$ ve $1 \mathrm{mg} \mathrm{L}^{-1}$ IBA içeren MS ortamında, boğumarası eksplantları için $1 \mathrm{mg} \mathrm{L}^{-1} \mathrm{BAP}+0.5 \mathrm{mg} \mathrm{L}$ ${ }^{1}$ IBA içeren MS ortamında ve kök ekspalantı için 0.5 $\mathrm{mg} \mathrm{L}^{-1} \mathrm{BA}+0.5 \mathrm{mg} \mathrm{L}^{-1} \mathrm{IAA}$ içeren MS ortamında elde etmiştir. Pawar ve ark. (2015) Stevia rebaudiana'nın boğum eksplantları ile yürüttükleri çalışmada en yüksek sürgün sayısını BAP'ı en fazla oranda içeren (2.0 $\left.\mathrm{mg} \mathrm{L} \mathrm{L}^{-1}\right)$ kültür ortamında elde ettiklerini bildirmiştir. Buna karşın Naik ve ark. (2015) 0.5-2.5 mg L ${ }^{-1}$ BAP içeren MS ortamında Psophocarpus tetragonolobus'un sürgün ucu eksplantlarından en düşük sürgün sayısını $0.5 \mathrm{mg} \mathrm{\textrm {L } ^ { - 1 }} \mathrm{BAP}$ içeren $\mathrm{MS}$ ortamında elde ettiklerini bildirmiştir. Bu sonuçlar, bitki çeşidinin ve hormon oranının sürgün sayısı üzerinde etkili olduğu göstermektedir.

Sürgün uzunlukları BAP'ın tek kullanıldığı MS ortaminda 1.84-4.6 cm, BAP + IBA eklenmiş MS ortamında 2.50-4.52 cm arasında kaydedilmiştir. En uzun sürgünler $\mathrm{MS}+0.1 \mathrm{mg} \mathrm{\textrm {L } ^ { - 1 }} \mathrm{BAP}$ ortamında (4.6 $\mathrm{cm})$ ve $0.1 \mathrm{mg} \mathrm{L}^{-1} \mathrm{BAP}+0.1 \mathrm{mg} \mathrm{L}^{-1} \mathrm{IBA}$ eklenmiş $\mathrm{MS}$ ortamında $(4.6 \mathrm{~cm})$ elde edilmiştir. Her iki hormon uygulamasında da en kısa sürgünler $1.6 \mathrm{mg} \mathrm{L}^{-1} \mathrm{BAP}$ eklenmiş MS ortamında tespit edilmiştir. Çoğaltım ortamında BAP konsantrasyonlarının artması, sürgün uzunluğunu negatif yönde etkiler göstermiştir. 
Karataş ve Aasim (2015) L. nummularia’nın sürgün ucu, 1. ve 2. boğum eksplantlarmı $0.25-1.25 \mathrm{mg} \mathrm{L}^{-1}$ BAP ve $0.25 \mathrm{mg} \mathrm{L}^{-1} \mathrm{NAA}$ içeren MS ortamında kültüre almışlardır. Uzun sürgünleri genel olarak BAP'ı düşük oranda içeren kültür ortamında tespit etmişlerdir. En uzun sürgünleri ise sürgün ucu eksplatında $2.19 \mathrm{~cm}$ ile $0.5 \mathrm{mg} \mathrm{L}^{-1} \mathrm{BAP}+0.25 \mathrm{mg} \mathrm{L^{-1 }} \mathrm{NAA}$, 1. boğum eksplantında $2.25 \mathrm{~cm}$ ile $0.25 \mathrm{mg} \mathrm{L}^{-1} \mathrm{BAP}, 2$. boğum eksplantında $2.33 \mathrm{~cm}$ ile $0.25 \mathrm{mg} \mathrm{L}^{-1} \mathrm{BAP}+0.25 \mathrm{mg} \mathrm{L}$ ${ }^{1}$ NAA içeren MS ortamında kaydetmişlerdir. Silué ve ark. (2016) Vigna subterranea (L.) Verdc.'nın sürgün ucu eksplantında en yüksek sürgün uzunluklarını BAP'ı en fazla içeren kültür ortamında elde etmişlerdir. Bu sonuçlardan anlaşılacağı üzere, BAP hormon etkisinin bitki çeşidine, hormon oranına ve eksplant çeşidine göre değişebilmektedir.

Kültür ortamlarında üretilen rejenere bitkiler yoğun oranda kök oluşturdukları için ayrıca köklendirme çalışması yürütülmemiştir. Bitkiler üzerinde besin ortamı, dikkatlice uzaklaştırıldıktan sonra dış koşullara alıştırılması için akvaryum ortamına aktarılmıştır. Dört hafta sonunda bitkilerin boylarında ve köklerinde uzamalar gözlenmiş ve bitkilerin dış koşullara alıştırılması başarıyla sağlanmıştır. Benzer şekilde doku kültürü teknikleri ile üretilen L. nummularia (Zheng ve ark. 2009; Karataş ve Aasim, 2015), C. demersum (Dogan ve ark., 2015, Pogostemon erectus (Dalzell) Kuntze (Dogan ve ark., 2016), V. subterranea (Silué ve ark., 2016) Rotala rotundifolia (Buch-Ham. ex Roxb) (Dogan, 2017) ve Sesamum indicum L. (Zimik ve Arumugam, 2017) bitkileri de dış koşullara alıştırılmıştır.

\section{SONUÇ}

L. nummularia tıbbi ve süs amaçlı kullanılan önemli bir bitkidir. Bu çalışmada doku kültürü teknikleri ile L. nummularia'nın boğum eksplantlarından mikroçoğaltımı başarıyla sağlanmıştır. Çalışmada iki farklı hormon uygulaması yapılmış olup, en fazla sürgün sayısı ve en uzun sürgünler BAP'ın tek kullanıldığı kültür ortamında elde edilmiştir. Genel olarak kültür ortamlarında kullanılan BAP hormon oranının artması ile sürgün sayısı artış gösterirken, sürgün uzunluğu ise azalış göstermiştir. Çoğaltılan bitkiler ex vitro koşullara başarıyla alıştırılmıştır. Tıbbi ve aromatik bitkilerin farmakolojik aktivitesi ve tıbbi ürünler olarak gelecekteki potansiyel uygulamaları giderek artış göstermektedir. Tıbbi bitki olan L. nummularia'nın çoklu üretimine imkan sağlayan bu çalışma sayesinde, bu bitkiden çeşitli biyoaktif bileşiklerin üretimi artırılabilir. Böylece gıda ve farmasötik/tıbbi sektörlerde kullanımına yardımcı olabilir.

\section{TEŞEKKÜR}

Bu çalışma, Türkiye Bilimsel ve Teknolojik Araştırma Kurumu (TÜBİTAK) tarafından 2130190 numaralı proje ile desteklenmiştir. Desteklerinden dolayı TÜBİTAK'a teşekkür ederim.

\section{KAYNAKLAR}

Baskaran P, Kumari A, Van Staden J 2018. In Vitro Propagation Via Organogenesis and Synthetic Seeds of Urginea altissima (L.f.) Baker: A Threatened Medicinal Plant. 3 Biotech, 8: 18.

Başaran MS, Adıgüzel N 2001. Bolu, Bartın ve Zonguldak İlleri Fındık Bahçelerinin Florasının Tespiti. Bitki Koruma Bülteni, 41(1-2): 39-66.

Challam M, Roy B, Tandon V 2010. Effect of Lysimachia ramosa (Primulaceae) on Helminth Parasites: Motility, Mortality and Scanning Electron Microscopic Observations on Surface Topography. Veterinary Parasitology, 169(1-2), 214-218.

Dias MI, Sousa MJ, Alves RC, Ferreira ICFR 2016. Exploring Plant Tissue Culture to Improve the Production of Phenolic Compounds: A Review. Industrial Crops and Products, 82: 9-22.

Dogan M 2017. Multiple Shoot Regeneration from Shoot Tip and Nodal Explants of Rotala rotundifolia (Buch-Ham. ex Roxb) Koehne. Anatolian Journal of Botany, 1(1):4-8.

Dogan M, Karatas M, Aasim M 2015. An Efficient In Vitro Plantlet Regeneration of Ceratophyllum demersum L., An Important Medicinal Aquatic Plant. Fresenius Environmental Bulletin, 24(10b): 3499-3504.

Dogan M, Karatas M, Aasim M, 2016. In Vitro Shoot Regeneration From Shoot Tip and Nodal Segment Explants of Pogostemon erectus (Dalzell) Kuntze, A Multipurpose Ornamental Aquatic Plant. Fresenius Environmental Bulletin, 25(11): 47774782.

Ebrahimi M, Mokhtari A, Amirian R 2018. A Highly Efficient Method for Somatic Embryogenesis of Kelussia odorotissima Mozaff., An Endangered Medicinal Plant. Plant Cell, Tissue and Organ Culture, 132: 99-110.

Hanganu D., Olah NK, Mocan A,Vlase L, Benedec D, Raita O, Toma CC 2016. Comparative Polyphenolic Content and Antioxidant Activities of Two Romanian Lysimachia Species. Revista de Chimie, 67(2): 227-231.

Hussain A, Qarshi IA, Nazir H, Ullah I 2012. Plant Tissue Culture: Current Status and Opportunities. (Recent Advances in Plant In Vitro Culture, InTech, Croatia, Ed: Leva A, Rinaldi LMR) 1 p.

Jafari N, Othman RY, Khalid N, 2011. Effect of Benzylaminopurine (BAP) Pulsing on In Vitro Shoot Multiplication of Musa acuminata (banana) cv. Berangan. African Journal of Biotechnology, 10(13): 2446-2450.

Karataş M, Aasim M 2015. In Vitro Plantlet Regeneration from Nodal Segments of Creeping Jenny (Lysimachia nummularia L.) - a Medicinal 
Aquatic Plant. Fresenius Environmental Bulletin, 24(4): 1263-1268.

Karatas M, Dogan M, Emsen B, Aasim M 2015. Determination of In Vitro Free Radical Scavenging Activities of Various Extracts From In Vitro Propagated Ceratophyllum demersum L.. Fresenius Environmental Bulletin, 24(9a): 29462952.

Kodela PG, Jobson RW 2016. Lysimachia nummularia (Primulaceae) Naturalised in New South Wales, Australia. Journal of Plant Systematics, 19: 153157.

Kumar V, Moyo M, Staden JV 2017. Somatic Embryogenesis in Hypoxis hemerocallidea: An Important African Medicinal Plant. South African Journal of Botany, 108: 331-336.

Li HY, Hao Z, Wang X, Huang L, Li JP 2009. Antioxidant Activities of Extracts and Fractions from Lysimachia Foenum-Graecum Hance. Bioresource Technology, 100(2): 970-974.

Murashige T, Skoog F 1962. A Revised Medium for Rapid Growth and Bioassays with Tobacco Tissue Cultures. Physiological Plantarum, 15: 473-497.

Naik DSR, Prasad B, Nemali G, Naik AS 2015. In Vitro Shoot Proliferation From Shoot Tip Explants of Winged Bean (Psophocarpus tetragonolobus). International Journal of Recent Scientific Research, 6(5): 3985-3987.

Neumann KH, Kumar A, Imani J 2009. Plant Cell and Tissue Culture - A Tool in Biotechnology, Principles and Practice, Springer-Verlag Berlin Heidelberg, Germany, 1 p.

Pawar SV, Khandagale VG, Jambhale VM, Jadhav AS, Pawar BD 2015. In Vitro Regeneration Studies in Stevia Through Nodal Segment and Shoot Tip. The BioScan, 10(3): 1007-1010.

Podolak I, Koczurkiewicz P, Galanty A, Michalik M 2013a. Cytotoxic Triterpene Saponins from the Underground Parts of Six Lysimachia L. Species. Biochemical Systematics and Ecology, 47: 116-120.

Podolak I, Koczurkiewicz P, Michalik M, Galanty A, Zajdel P, Janeczko Z 2013b. A new Cytotoxic Triterpene Saponin from Lysimachia nummularia L.. Carbohydrate Research, 375:16-20.

Sharma SK, Patil A, Agnihotri AK, Mehrotra S 2018. In Vitro Conservation of Alectra chitrakutensis: a Critically Endangered Root Parasitic Plant of High Medicinal Importance. Acta Physiologiae Plantarum, 40: 29.
Silué N, Koné T, Soumahoro AB, Koné M 2016. In Vitro Shoot Tip Multiplication of Bambara Groundnut [Vigna subterranea (L.) Verdc.]. Plant Cell Tissue and Organ Culture, 127(3): 603-611.

Soni V, Bhushan M 2017. Hormonal Control of Morphogenesis In Vitro in Nodal Segments of Tylophora indica. International Journal of LifeSciences Scientific Research, 3(4): 1250-1252.

Toth A, Toth G, Kery A 2014. Polyphenol Composition and Antioxidant Capacity of Three Lysimachia species. Natural Product Communications, 9: 14731478.

Toth ER, Vegh K, Alberti A, Beni S, Kery A 2017. Contribution of Individual Flavonoids in Lysimachia species to the Antioxidant Capacity based on HPLC-DPPH Assay. Natural Product Research, 2017:1-4.

Trivedi DR, Joshi AG 2014. In Vitro Shoot Regeneration of Stereospermum suaveolens DC. Using Cotyledonary Node and Nodal Explants. Plant Tissue Culture and Biotechnology, 24(2): 235246.

Turker AU, Guner B 2013. Efficient Plant Regeneration of Yellow Loosestrife (Lysimachia vulgaris L.), a Medicinal Plant. Acta Biologica Hungarica, 64(2):218-30.

Yang X, Wang BC, Zhang X, Liu WQ, Qian JZ, Li W, Deng J, Singh GK, Su HJ 2011. Evaluation of Lysimachia christinae Hance Extracts as Anticholecystitis and Cholagogic Agents in Animals, 137: 57-63.

Yasukawa K, Ogawa H, Takido M 1990. Two Flavonol Glycosides from Lysimachia nummularia. Phytochemistry, 29(5): 1707-1708.

Yılmaz C, Kormaz H 2017. Terme'nin Biyoçeşitlilik ve Doğal Ortam Özellikleri. Serander Yayınları, Trabzon, Türkiye.

Zheng W, Xu XD, Dai H, Chen, LQ 2009. Direct Regeneration of Plants Derived from In Vitro Cultured Shoot Tips and Leaves of Three Lysimachia species. Scientia Horticulturae 122: 138-141.

Zimik M, Arumugam N 2017. Induction of Shoot Regeneration in Cotyledon Explants of the Oilseed Crop Sesamum indicum L.. Journal of Genetic Engineering and Biotechnology, 15(2): 303-308. 